\title{
Europium(III) Catalyzed Recyclization of 2-(5-Isoxazolyl)phenol: Synthesis and Structure of Benzopyran Derivative
}

\author{
Yunghee Oh, Chul Ho Lee, Jae Soo Choi, and Sung Kwon Kang ${ }^{\dagger *}$ \\ Department of Chemistry, Dongeui University, Pusan 614-714, Korea \\ "Department of Chemistry, Chungnam National University, Daejeon 305-764, Korea. "E-mail: skkang@)cnuac.kr \\ Received October 9, 2007
}

Key Words : Benzopyran, Recyclization, Europium, Isoxazolylphenol, X-ray structure

Europium complexes exhibits sharp red emission bands due to its $4 \mathrm{f}$ electrons. Especially those coordinated by chelating oxygen ligands such as $\beta$-diketones show good stability in the air and can be used as red emitting materials.' To improve the emitting color or luminescence efficiency, neutral nitrogen donating ligand such as phenanthroline or 2,2 -bipyridine was added to the Eu compound coordinated by oxygen donating ligands. ${ }^{1}$ However, Eu compounds only with nitrogen donating ligands especially with aromatic nitrogens $\mathrm{s}^{2.3}$ are not much compared to the oxygen ligated $\mathrm{Eu}$ compounds due to weaker metal-nitrogen interaction. ${ }^{3+}$ We had reported that $\mathrm{Eu}$ (III) complex obtained from the reaction of $\mathrm{EuCl}_{3}$ and $2,2^{\prime}$-dipyridylamine was decomposed to $2,2^{\prime}$ dipyridinium chloride and Eu compound in methanol solution.

Herein, we investigate new Eu(III) complexes coordinated by both of nitrogen and oxygen by using 2-(5-isoxazolyl)phenol ligand in the same condition as corresponding 2,2'dipyridylamine reaction.

\section{Experimental Section}

When $\mathrm{EuX}_{3}\left(\mathrm{X}=\mathrm{NO}_{3}, \mathrm{Cl}\right.$ ) reacted with 2-(5-isoxazolyl)phenol in the ethanol solution, a recyclized product, benzopyran derivative $(\mathbf{I})$, was produced.

$2 \mathrm{M} \mathrm{NaOH}$ solution ( $3 \mathrm{~mL}, 6 \mathrm{mmols}$ ) was added to $2-(5-$ isoxazolyl)phenol $(0.484 \mathrm{mg}, 3 \mathrm{mmols})$ and ethanol $(20$ $\mathrm{mL}$ ). The mixture was stirred for about $30 \mathrm{~min}$. until the color changed to yellow. Ethanol $(20 \mathrm{~mL})$ solution of $\mathrm{EuX}_{3} \cdot \mathrm{nH}_{2} \mathrm{O}$ (1 mmol) was added to the yellowish ligand solution followed by stirring another I hour at room temperature. Filtered off the salts, the filtrate was stood for I week in the air. White crystals were filtered, washed with cold ethanol and dried in vacuum; Yield $89 \%, \operatorname{mp} 270^{\circ} \mathrm{C},{ }^{\prime} \mathrm{H}$

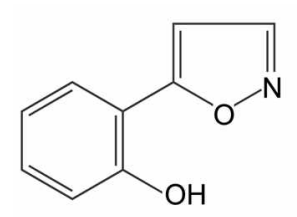

2-(5-Isoxazolyl)phenol

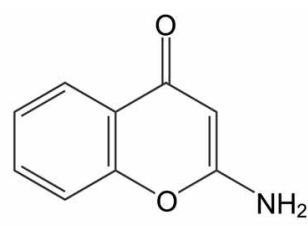

I
Figure 1. 2-(5-Isoxazolyl)phenol and 4H-1-benzopyran-2-amino4-one (I).
NMR $\left(300 \mathrm{MHz}, \mathrm{CD}_{3} \mathrm{OD}, 25^{\circ} \mathrm{C}\right) 7.2-8.2 \mathrm{ppm}$. At the first stage of the reaction, Eu complex was produced. It was evidenced by red light emission of the product, which is the typical property of Eu(III) complex. ${ }^{6}$ When the reaction mixture was kept for one week, new organic compound, $\mathbf{I}$, was produced, not containing Eu metal.

The data for $\mathrm{X}$-ray structure determination was collected on a $\mathrm{CAD}-4$ diffractometer equipped with graphite monochromated Mo $\mathrm{K} \alpha$ radiation $(\lambda=0.71073 \AA$ ) at $295 \mathrm{~K}$. The unit cell dimensions were determined on the basis of 22 reflections in the range of $8.03^{\circ}<\theta<13.14^{\circ}$. The data was collected by the $\omega / 2 \theta$ scan mode. The standard direct method was used to position the heavy atoms. The remaining non-hydrogen atoms were located from the subsequent difference Fourier synthesis. All non-hydrogen atoms were refined anisotropically. All hydrogen atoms were calculated in ideal positions and were riding on their respective carbon atoms $\left(B_{\mathrm{iat}}=1.2 B_{\mathrm{eq}}\right)$. The structure was refined in a full matrix least-squares calculation on $F^{2}$. Program used to solve structure and to refine structure; SHELXS97 and SHELXI 97.7 Molecular graphics; Ortep-3 for windows.

Crystallographic data for the structures reported here have been deposited with the Cambridge Crystallographic Data Centre (Deposition No. CCDC-660511). The data can be obtained free of charge via www.ccdc.cam.ac.uk/deposit (or from the $\mathrm{CCDC}, 12$ Union Road, Cambridge CB2 1EZ, UK; Fax: +44-01223 336033; E-mail: deposit(a)ccdc.cam.ac.uk).

\section{Results and Discussion}

The compound I emits green light when it is excited by uv light. It is clear that Eu(III) catalyzes the formation of $\mathbf{I}^{9}$ When 2-(5-isoxazolyl)-phenol was reacted with base without Eu(III), I was not produced. The Eu(III) catalytic reaction can be used to synthesize organic compounds containing nitrogen atom especially benzopyrans, which are now interestingly investigated because of its biological activities. ${ }^{10}$ Although, at this stage, we have not thoroughly figured out the reaction mechanism, we are still investigating the reaction mechanism including recyclization. We propose an Eu complex ligated by nitrogen as well as oxygen before nitrogen-oxygen cleavage as an intermediate as shown in Figure 2. As the intermediate of Eu complex coordinated by nitrogen donating ligand is unstable in the 


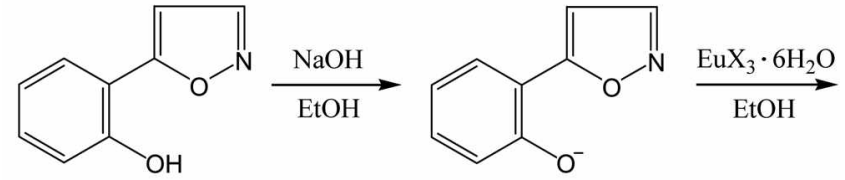

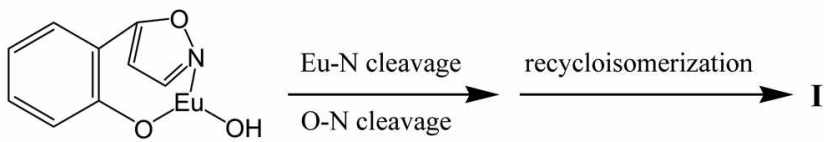
proposed intermediate

Figure 2. Synthetic Route of I.

Table 1. Crystal data and structure refinement for $\mathrm{I}, \mathrm{C}_{9} \mathrm{H}_{7} \mathrm{NO}_{2}$

\begin{tabular}{ll}
\hline Chemical formula & $\mathrm{C}_{9} \mathrm{H}_{7} \mathrm{NO}_{2}$ \\
Formula weight & 161.16 \\
Temperature & $295(2) \mathrm{K}$ \\
Wavelength & $0.71073 \AA$ \\
Crystal system, space group & Monoclinic, $\mathrm{P} 2(1) / \mathrm{c}$ \\
Unit cell dimensions & $a=7.1869(14) \AA \quad a=90^{\circ}$ \\
& $b=10.156(2) \AA \quad \beta=102.89(3)^{\circ}$ \\
& $c=10.575(2) \AA \quad \gamma=90^{\circ}$ \\
Volume & $752.4(3) \AA^{3}$ \\
Z, Calculated density & $4,1.423 \mathrm{mg} / \mathrm{m}^{3}$ \\
F(000) & 336 \\
Crystal size & $0.23 \times 0.2 \times 0.2 \mathrm{~mm}$ \\
Reflections collected/unique & $1478 / 1399\left[\mathrm{R}_{\mathrm{int}}=0.0540\right]$ \\
Data/restraints/parameters & $1399 / 0 / 109$ \\
Goodness-of-fit on $\mathrm{F}^{2}$ & 0.962 \\
Final R indices $[P 2 \sigma(I)]$ & $R 1=0.0790, w R 2=0.1145$ \\
$R$ indices (all data) & $R 1=0.2444, w R 2=0.1635$ \\
Largest diff. peak and hole & 0.207 and -0.289 eA \\
\hline
\end{tabular}

reaction condition, it will be decomposed to organic compound $\mathbf{I}$ and Eu compound. ${ }^{\text {? }}$

The crystallographic data and structure refinement parameters of $\mathbf{I}, \mathrm{C}_{9} \mathrm{H}_{7} \mathrm{NO}_{2}$, are summarized in Table 1 . The selected bond distances and bond angles are summarized in Table 2. And an ORTEP view of including the atomic numbering scheme is shown in Figure 3. All atoms in $\mathbf{I}$ are

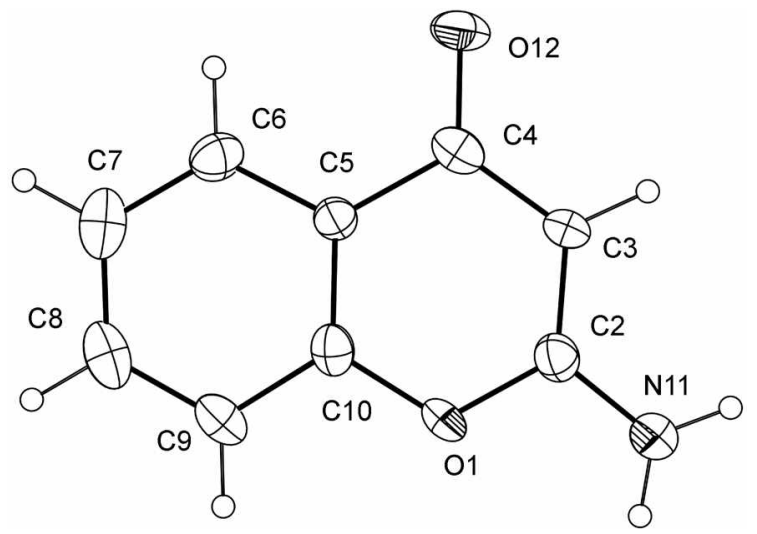

Figure 3. ORTEP diagram of $\mathrm{C}_{9} \mathrm{H}_{7} \mathrm{NO}_{3}$, showing the atom mimbering scheme.
Table 2. The selected bond distances $(\AA)$ and angles $\left({ }^{\circ}\right)$ of $I$, $\mathrm{C}_{9} \mathrm{H}_{7} \mathrm{NO}_{2}$

\begin{tabular}{llll}
\hline $\mathrm{O}(1)-\mathrm{C}(2)$ & $1.355(6)$ & $\mathrm{O}(1)-\mathrm{C}(10)$ & $1.387(5)$ \\
$\mathrm{C}(2)-\mathrm{N}(11)$ & $1.322(6)$ & $\mathrm{C}(2)-\mathrm{C}(3)$ & $1.359(7)$ \\
$\mathrm{C}(3)-\mathrm{C}(4)$ & $1.403(7)$ & $\mathrm{C}(4)-\mathrm{O}(12)$ & $1.247(6)$ \\
$\mathrm{C}(4)-\mathrm{C}(5)$ & $1.465(7)$ & $\mathrm{C}(5)-\mathrm{C}(10)$ & $1.381(7)$ \\
& & & \\
$\mathrm{C}(2)-\mathrm{O}(1)-\mathrm{C}(10)$ & $118.4(5)$ & $\mathrm{N}(11)-\mathrm{C}(2)-\mathrm{O}(1)$ & $111.6(5)$ \\
$\mathrm{N}(11)-\mathrm{C}(2)-\mathrm{C}(3)$ & $125.2(6)$ & $\mathrm{O}(12)-\mathrm{C}(4)-\mathrm{C}(3)$ & $124.8(6)$ \\
$\mathrm{O}(1)-\mathrm{C}(2)-\mathrm{C}(3)$ & $123.2(6)$ & $\mathrm{C}(2)-\mathrm{C}(3)-\mathrm{C}(4)$ & $121.8(6)$ \\
\hline
\end{tabular}

Table 3. Hydrogen bonding geometries $\left(\lambda,{ }^{\circ}\right)$ of $\mathrm{I}, \mathrm{C}_{9} \mathrm{H}_{7} \mathrm{NO}_{2}$

\begin{tabular}{lcccc}
\hline $\mathrm{D}-\mathrm{H} \cdots \mathrm{A}$ & $\mathrm{d}(\mathrm{D}-\mathrm{H})$ & $\mathrm{d}(\mathrm{H} \cdots \mathrm{A})$ & $\mathrm{d}(\mathrm{D} \cdots \mathrm{A})$ & $\mathrm{C}(\mathrm{DHA})$ \\
\hline $\mathrm{N}(11) \mathrm{H}(11 \mathrm{~A}) \ldots \mathrm{O}(12) \# 1$ & 0.86 & 2.14 & $2.921(6)$ & 150.4 \\
$\mathrm{~N}(11)-\mathrm{H}(11 \mathrm{~B}) \ldots \mathrm{O}(12) \# 2$ & 0.86 & 2.09 & $2.876(6)$ & 150.9 \\
\hline
\end{tabular}

Symmetry transfomations used to generate equivalent atons: $+1 / 2, z+1 / 2 \quad \# 2-x+1, y+1 / 2,-z+1 / 2$

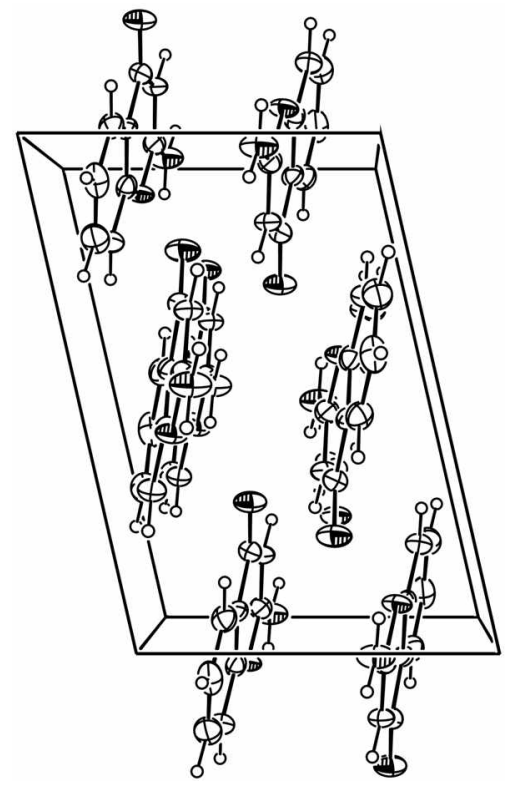

Figure 4. $\Lambda$ molecular packing diagram of $\mathrm{C}_{9} \mathrm{H}_{7} \mathrm{NO}_{2}$, viewing normal to $b$-axis.

placed at the same plane, which means this molecule is a conjugated system. The bond distances of O1-C2 (1.355(6) $\AA)$ and $\mathrm{O} 1-\mathrm{C} 10(1.387(5) \AA)$ are much shorter than the normal $\mathrm{C}-\mathrm{O}$ single bond of $1.416 \AA$. The $\mathrm{C} 2-\mathrm{N} 11$ distance of $1.322(6) \AA$ is also shorter than the typical C-N single bond distance of $1.474 \AA$. ." These bond distances and angles are also supporting the conjugated system in the heterocyclic ring. Figure 4 shows a molecular packing diagram for $\mathbf{I}$ in solid. The molecules are weakly held together by $\mathrm{N}-\mathrm{H} \cdots \mathrm{O}$ hydrogen bonds in the unit cell. The hydrogen bond distances and angles are summarized in Table 3.

In conclusion, benzopyran derivative, $4 \mathrm{H}-1$-benzopyran 2amino-4-one (I), was prepared from the reaction of 2-(5isoxazolyl)phenol and $\mathrm{EuX}_{3}\left(\mathrm{X}=\mathrm{NO}_{3}, \mathrm{Cl}\right)$. The compound I emits green light when irradiated by UV light. Structure of I was characterized by single crystal X-ray and 'H NMR 
methods. A proposed intermediate, Eu(III) complex coordinated by nitrogen donating ligands might be unstable and decomposed to organic and metal compounds. The mechanistic study is in progress.

Acknowledgement. This work was supported by Dongeui University Foundation Grant (2005AA096). X-ray data were collected at the Center for Research Facilities in Chungnam National University.

\section{References}

1. (a) Paw, W.; Cummings, S. D.; Mansour, M. A.; Geiger, D. K.; Eisenberg, R. Coord. Chem. Rev, 1998, 171, 125. (b) Wu, F. B.; Zhang, C. Analyt. Biochem, 2002, 31, 57. (c) Liu, H.-G; Jang, K.; Feng, X.-S.; Kim, C.; Yoo, Y.-J.; Lee, Y.-I. Bull. Kor. Chem. Soc. 2005, 26, 1969. (d) Kang, J.-G.; Kim, T.-J. Butl. Kor. Chent. Soc. 2005, 26, 1057. (e) Kido, J.; Okamoto, Y. Chem. Rev: 2002. 102(6), 2357

2. Mazzanti, M.; Wietzke, R; Pecaut, J.; Latour, J.-M.; Remy, M. Inorg. Chem. 2002, 41, 2389.

3. Wietzke, R.; Mazzanti, M.; Latour, J.-M. Inorg. Chem, 1998, 37, 6690

4. Melby, L. R.; Rose, N. J.; Abramson, E.; Caris, J. C. J. Am. Chent.
Soc, 1964, 86,5117.

5. Oh, Y.; Lee, C.; Lee, B.; Shin, B. Key Engintering Mater. 2005, $277=279,966$.

6. When we evaporated all the solvent the residual white solid shows red light emisssion by uv light. We could not characterized the structure as it turned to the Compound I during the recrystalization process.

7. Sheldrick, G. M. SHELXS97 and SHELLZ 97, Program for the Refinement of Crystal Structures; University of Göttingen: Germany, 1997.

8. Farrugia, L. J. J. Appl. Chyst, 1997, 30,565.

9. For example of metal-calalyzed cyclization, see (a) Seregin, I. V; Gevorgyan, V. J. Am. Chem. Soc. 2006, 128, 12050. (b) Dubé, P. Toste, F. D. J. Am. Chem. Soc. 2006, I28, I2062. (c) Anniyappan, M.: Muralidharan, D.; Perumal, P. T. Tetrahedron 2002, 58, 10301.

10. (a) Roma, G.; Cinone, N.; Braccio, M. D.; Grossi, G.; Leoncini, G.; Signorello, M. G.; Carotti, A. Bioorg. Medicin. Chem. 2000, 8, 75I. (b) Kim, N.; Lee, S.; Yi, K. Y.; Yoo, S.; Lee, C. O.; Park, S. H.; Lee, B. H. Bioorg. Medicin. Chem. Lett. 2003, J3, 166I. (c) Salim, A. A.; Pawlus, A. D.; Chai, H. B.; Farnsworth, N. R.; Kinghorn, A. D.; Carcache-Blanco, E. J. Bioorg, Medicin. Chent. Lett. 2007, I7(1), 109. (d) Koufaki, M.; Kiziridi, C.; Papazafiri, P.; Vassilopoulos, A.; Varr, A.; Nagy, Z.; Farkas, A.; Makriyannis, A. Bioorg. Medicin. Chem. Lett, 2006, 14, 6666.

11. Wells, A. F. Structural Inorganic Chemistry, 5th ed.; Oxford University Press: 1984. 